\title{
The study of the influence of ancient Greek rituals and sports and the formation of the architecture of its sports spaces
}

\author{
1 Department of Architecture, Faculty of Civil and Architecture, Malayer University ,Malayer, Iran. $\left(^{*}\right)$ Corresponding author. \\ E-mail: n.deimary@malayeru.ac.ir (iD https://orcid.org/0000-0001-7998-0395 \\ 2 MA Student of Architecture Technology, Shahid Beheshti University, Tehran, Iran. \\ E-mail: mahsa_azz@yahoo.com (iD https://orcid.org/0000-0001-7998-0568 \\ 3 Department of Physical Education, Faculty of Literature and Humanities, Malayer University, Malayer, Iran. \\ E-mail: m.mohammadi@malayeru.ac.ir (iD https://orcid.org/0000-0002-4180-3921
}

Nima Deimary ${ }^{1 *}$

Mahsa Azizi²

Mohammad Mohammadi ${ }^{3}$

\begin{abstract}
To get a better understanding of why variety of sports buildings are this massive in ancient Greece, a proper understanding of the history of sports as well as Greece itself must start at the beginning. Greece is a country that is enclosed with hills and mountains alongside short rivers and fertile va lleys. Even though Greek people were living in separate city-states, they were united under national pride, common temples, same rituals and games like Olympic. Sports were the most important parts of most Greek men. Gym and music alongside each other, fed the body and the soul of the athletes. They admired the beauty of well-trained men. They believed in multiple gods who were living in Holy mount of Olympus under the reign of greater god, Zeus and they held many rituals to satisfy them and Olympic was the most famous rituals amongst others. A ceremony in honor of Zeus was held in Olympia.

Keywords: Ancient Greece. Sports. Stadium. Gymnasium. Palaestra. Olympic
\end{abstract}

\section{INTRODUCTION}

To begin talking about sports in Greece, we need to start with Aegean sea civilizations such as Crete. We can trace sports and games to about 2500 years B.C. in Crete, where there is a picture of three acrobats playing with a large cow, who might be a symbol of Zeus in Knossos. Also in Acroteria, we saw a wall painting of two young boxers wearing gloves.

Regretfully we do not know much about Aegean civilizations, so we need to continue with the most famous sports event in Greece, the Olympic Games. The Olympic Games were held every four years since 776 B.C in honor of Zeus. This is the official date that the Olympic Games was founded, but its unofficial beginning dates back farther. Sacrifices and gifts were offered, and athletes swear to obey the rules before the statue of Zeus. Olympic Games originally treated sporting competitions as a form of religious ritual. Greek people used the games to communicate with their gods.

Olympia was well known to the ancient world for its sanctuary of Zeus. According to tradition, Iphitus, king of Elis, wishing to end the calamities that had befallen his kingdom, asked the Oracle at Delphi for advice. The prophetess Pythia commanded Iphitus and the people of Elis to establish the Olympic Games. In 776 BCE, the ancient Greeks began travelling to Olympia every four years to take part in sporting competitions. According to the poet Pindar, Heracles ran a race here in celebration of one of his labors, and decreed that it should be repeated every four years.

The games were announced by heralds 
travelling to the Greek cities, and hostilities were banned during the period around the games to safeguard those travelling to Olympia. In the spring of an Olympic year, three sacred heralds would set out from Olympia to visit every corner of the Greek world and announce the forthcoming games.

Each Greek city-state sent its best men to Olympia, determined by local elimination trials. The games lasted three days, and nude athletes started the competitions. The winner would be awarded with a branch of wild olive, but the rewards were great in other ways. The crowds idolized the great athletes, poets wrote odes to their triumphs, and sculptors immortalized them in bronze and marble. From the fifth century onward, monetary rewards also became associated with an Olympic championship.

The Olympic Games ended when the games were banned by Emperor Theodosius 1 st in 393-4 A.D. And finally, the town of Olympia disappeared soon after it was destroyed by the Goths.

There were many more games like Olympic which would gather athletes from across all Greece. Games such as Isthmian, Pythian and Nemean -alongside Olympic, were called Panhellenic Games.

Isthmian games were held every two years, and athletes, horse riders and musicians would participate in them. These games were held in honor of Poseidon -the god of seas- in Isthmia, Sicyon. Yachting was an important part of Isthmian games because of Poseidon. The very first record of Isthmian games was back in 581 B.C.

Pythian games were held every four years and included chariot race, horse race and music and lasted for 15 days. Pythian games were held in honor of python goddess who was killed by Apollo in the sacred city of Delphi way back in 582 B.C.
Fig 1. Bull leaping in Knossos

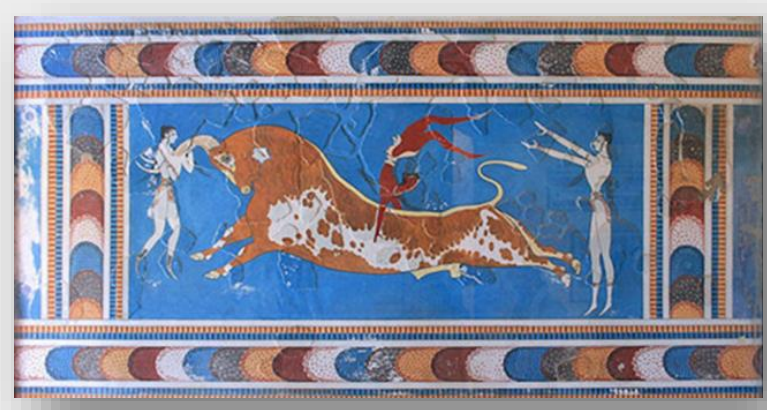

\section{THE GAMES}

\section{Pentathlon}

The most important Greek Olympic games was called Pentathlon or Five Races. The Greek pentathlon featured discus, javelin, jumping, running and wrestling and the individual who would win these five games became a super hero.

The pentathlon was held during the afternoon of the second Olympic day. The athletes had to participate in five events. All events except the final event, wrestling, were held in the stadium, while the wrestling took place in an open area near the altar of Zeus.

According to Burns, the Program of Events in Olympic are as follows:

Day One: Morning: Swearing-in ceremony. Contests for heralds and trumpeters. Boys' running, wrestling and boxing contests. Prayers and sacrifices in the sanctuary of Zeus; consultation of oracles.

Afternoon: Speeches by philosophers, poets and historians. Tours of the sanctuary of Zeus. Reunions with old friends.

Day Two: Morning: Procession in the hippodrome of competitors in the equestrian events. Chariot and horse-races.

Afternoon: The pentathlon. Evening: $\mathrm{Fu}-$ neral rites in honor of the hero, Pelops. $\mathrm{Pa}$ rade of visitors around the sanctuary of Zeus. Singing of victory hymns. Feasting and revel- 
ry.

Day Three: Morning: Procession of the judges, ambassadors, competitors, and sacrificial animals to the Great Altar.

Afternoon: Running races.

Evening: Public banquet in the Prytaneion.

Day Four: Wrestling event. Midday: Boxing and the pankration (all-in-wrestling).

Day Five: Procession of victors to the Temple of Zeus, to be crowned by the judges with garlands of wild olive.

\section{Boxing}

Boxing was considered the most violent sport. Violent activity was what attracted the spectators and that was what they want to see.

There were no separate rounds in a match and the contestants fought until one of them gave in, knocked out or raised his hand as a sign of defeat.

In the early competitions, boxers wore soft leather thongs designed not to inflict injury but to protect the fingers. Leather thongs were wound tightly around the hands and wrists, leaving the fingers free. Blows were allowed with the fist and hand.

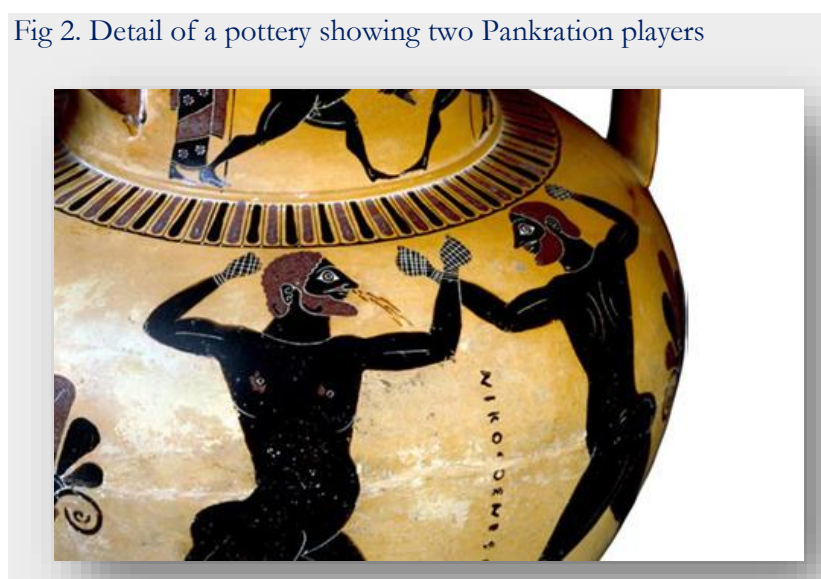

During training, they wore large soft pads called sphairai (spheres) to allow vigorous combat but avoid damage. To this end, they also wore ear-guards which Plutarch consid- ered more suitable for children in the proximity of a bout to prevent them from hearing the bad language that frequently accompanied the sport. The soft thongs were ultimately replaced by the 'sharp thongs'. These comprised a thin inner glove to which a pad of hard leather was intricately bound. The thronging carried up the forearm over a separate piece of sheepskin which was used, like the wrist-bandage some tennis players wear today as a device to wipe sweat quickly away from the brows.

\section{Pankration}

Arrichion of Phigaleia was the most famous of the 6th century pankratiasts. He won three times at Olympia in 572, 568 and 564 BC. He mentions: "Pankration is the most sublime game of the Olympic and also the most important and effective way of getting the army forces prepared. A Pankration athlete must be a great wrestler and a giant boxer at once.

Pankration means "all power/all force". It has been described as a mixture of boxing, wrestling and judo, a kind of scientific unarmed combat. Almost any tactic was permitted. Only biting and going for an opponent's eyes were illegal.

Its objective was to bring an opponent to a point where he was compelled to admit defeat, which he signified by holding up his arm. Locks and strangleholds were therefore permitted, but biting and gouging were forbidden.

Pankration was practiced in the Palaestra.

\section{Running}

Running was the dominant discipline in the games. The official history of the Olympic Games started with a race at a distance of one "stadium" (192.27 m). It was called the stadion race - a sprint of one stade (roughly $192 \mathrm{~m}$ ). 
Other races varied from 2-24 stades, and the hoplitodromos race featured athletes running in weighty armour demonstrating military prowess (the $400 \mathrm{~m}$ race in armor.)

Besides this equivalent of our 'twohundred meter' event, there was a race along two lengths of the track, and a long-distance race of twenty or twenty-four lengths. There was no 'marathon' - this was the invention of Baron de Coubertin who revived the Olympic Games in 1896. The long distance race ("Dolichos") is $4800 \mathrm{~m}$.

In all these races, the runners made a standing start, from a row of stone slabs set in the track that had grooves cut in them to provide a grip for the toes.

The historical accounts of the longer runs have left us with some unanswered questions. Was there one turning pole for runners, or separate turning poles for each athlete? There were rules against tripping and bumping, but ancient writers suggest that such tricks were frequent.

Since they were run on the same day, only a true extraordinary athlete could win all three sprinting events at the same games. Such an individual would be called a tripler.

\section{Chariot Race}

At Olympia, the chariot race was the opening event, but only after a previous day of preparation and worship. The two-wheeled chariots, each drawn by four horses abreast, entered the stadium in a ceremonial procession led by judges dressed in purple robes, a herald, and a trumpeter. As each chariot passed in front of the judges' stand, the herald would call out the names of the owner, his father, and his city. Then he would proclaim that the games were officially open.

The number of chariots varied up to 41 at the Pythian games in 462 B.C. A large field made an exciting contest because they all would start together and rush toward the turning post some $400 \mathrm{~m}$ away. The trumoeters would signal the start, and the chariots would make 12 laps, more than nine kilometers, around the turning posts.

Chariot races were very dangerous and required the most skillful drivers. The most dangerous place was at the turning post where chariot wheels could lock together and there were many crashes. Collisions were common on the narrow course, and it was not uncommon for only one chariot to complete the race.

In ancient Greece, only the wealthy could afford to maintain a chariot and horses. Chariots had been used to carry warriors into battle, and chariot races, along with other sports events were originally held at the funeral games of heroes, as described in Homer's Iliad. Wealthy citizens and Greek statesmen were anxious to win such a prestigious event. They sometimes drove their own chariot, but usually employed a charioteer. The races took place in an arena called the hippodrome.

After the dangers and excitement of the chariot race came the horse racing. This was hazardous because the track was already churned up, and the jockeys rode without stirrups or saddles, which were not yet invented. The winning horse and its owner were given an enthusiastic reception, and riderless horses that came first and past the post were also honored.

\section{Wrestling}

Wrestling was a sport of great skill which used many of the throws still seen today. It is also featured as part of the pentathlon.

The procedure was simple. Names were drawn from a silver urn setting up initial matches and creating the "pairing" of matches that would lead to the final or championship bouts. All three sports were brutal, with few rules, no time limits and no ring. There were also no weight classes, so the competition was 
limited to big, tough, and well-muscled men.

The objective in wrestling was to score three falls, a fall being defined as touching the ground with the knees.

Milo of Croton was one of the most famous of the legendary strong men who won this popular event. Milo won the boys' wrestling in 540 B.C. and the senior event at five successive games.

Presumably, biting or gouging was prohibited A fifth century B.C. wrestler named Leonticus from Messina in Sicily tried to break his opponent's fingers as quickly as possible. He was remembered as one of the first wrestlers to develop new "holds".

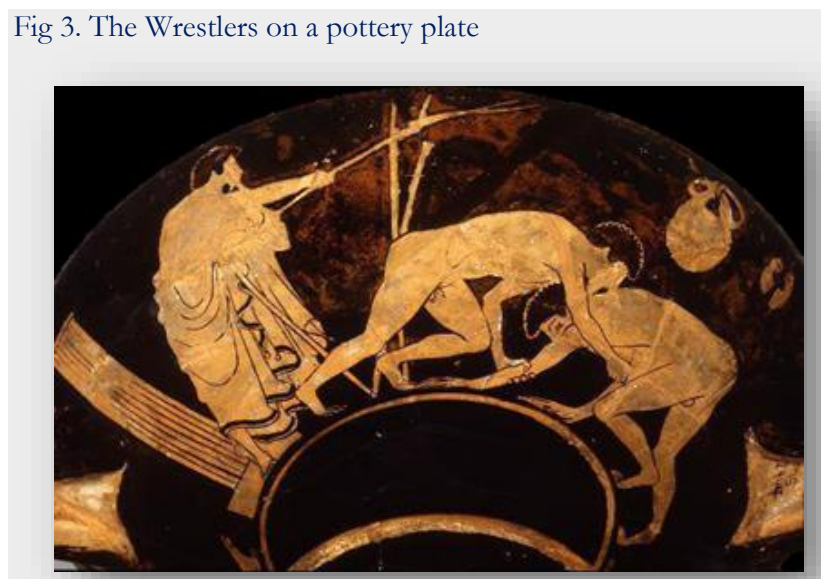

Two men wrestling were watched by a trainer from the University of Pennsylvania Museum of Archaeology and Anthropology.

Music education and gymnastic training were carried out in "Gymnasiums" and "Palestrae" which were built and controlled by the state; running areas were called "Dramos", and chariot race areas were termed "Hippodromes" (AYTAC, 1980).

\section{Olympia}

Olympia was not a formal settlement; it was a small sacred area surrounded by a wall containing the important sanctuary. It was named after the revered Mount Olympus which was believed to be the home of the gods. It was situated close to the river Kladeos, which in the fourth century CE changed its course, destroying part of the gymnasium. Eventually, floods and tsunamis destroyed most of the sanctuary and covered the remains with several meters of silt.

In the early days, the games were held near Zeus statue and the running game started right at Zeus statue`s feet. Some years after, a stadium was built there.

\section{Agora}

The agora of a Greek city-state was the center where political, religious, social, and commercial activities took place. In addition to the agora serving as the "gathering place" for these necessary functions, there is evidence which suggests that athletic activities took place here.

It was not until after Solon's time, in the early sixth century B.C. that the Athenian Agora became the market place and civic center of the city. Prior to that time, the area was conspicuously lacking public buildings as Athens had no physical trace of a city center or market place. Soon after Solon, however, the character of the area changed, and buildings whose main functions were political in nature began to appear. During the pre-Agora days, as early as the eighth century B.C., the area may have been a regular location for athletic contests. It seems that the site that eventually became Athens' commercial and civic center was intimately linked with athletic activities. This coupled with the prominence of chariot race scenes on the late Geometric vases from Athenian graves, reinforces the belief that chariot races were part of the funeral games in early Athens.

As the athletic activities and interests of the Athenians grew, the need for a larger area to accommodate spectators developed; hence, in the late fourth century B.C., the construction 
of the Panathenaic Stadium was begun. Upon its completion, the athletic events of the Agora were shifted to the new facility. In spite of the transfer of events to the new structure, the Agora was still regarded as an important location for the erection of statues by victorious athletes in honor of their success in the athletic games.

Athenian Agora remained the site of athletic happenings until the late fourth century B.C. when the new stadium displaced the Agora as the location for athletic activities.

Athens' leading festival was closely associated with the Agora and the Acropolis. A processional road known as the Panathenaic Way passed diagonally through the Agora and continued to the entrance to the Acropolis. According to Aristophanes, torch races started at the outer Kerameikos, passed through the Agora, and finished at the Acropolis.

Further physical proof of athletics in the Athenian Agora came to light when in the northwest sector of the area a row of five square limestone bases were found stretching across the width of the street. The bases were placed so that their tops were slightly elevated above the surface of the road. At the west end of the row of bases is a circular pit in which a round base originally existed. These bases appear to have been spaced with relation to the adjacent altar of the Twelve Gods and there is room for five additional bases between the altar and the pit.

The arrangement of bases which extended approximately $20 \mathrm{~m}$ across the Panathenaic Way resembles the starting line of a running track. The sockets were used to insert light wooden posts that served as a starting gate for running events. The starting gate was apparently controlled from the circular pit. Shear suggests that in the second half of the fifth century B.C., running contests of the Panathenaea with room to accommodate ten runners began at this line and proceeded across the center of the Agora. Furthermore, a discovery from Priene, an Ionic city in Asia Minor, confirms the use of individual bases as a starting line even though the arrangement is situated in a stadium rather than an Agora and is of a later date.

The Corinthian Agora offered a peculiar arrangement related to athletic competition, especially when one considers the fact that a combined running track and hippodrome may have existed in the center of the city. There is clear evidence of wheel ruts in the surface of the race course. Additionally, these ruts are significantly close to the starting line of the track used by runners. Also, there are indications that a retaining wall of a grandstand used by spectators to view wrestling, boxing, and pankration events, was cut back in order to prevent the crowding of chariots which attempted to negotiate a turn at this critical point. Although the combination of a running track and hippodrome in the center of a city may seem unusual, the arrangement at Corinth was by no means a prototype. According to Pausanias, a configuration of this kind existed in the Agora at Elis, the training site for the ancient Olympic Games.

The bowl-shaped platform that was located south of the starting line has been interpreted by Williams and Russell as an area where the contact sports of wrestling, boxing, and the pankration occurred. Their hypothesis differs from Broneer who suggests that semicircular areas served as the support structure for a grandstand area used by spectators to view the events that occurred on the race course or a judges' area.

The evolution of athletic activities in the Agoras of two of Greece's leading city-states appears to have been linked to the cult of the dead. For at Athens, as well as Corinth, the areas that eventually became designated as each city's market place originally functioned as cemeteries. As the respective Agoras became more formalized, the funerary link was retained; but emphasis shifted to more com- 
mercial and civic-oriented activities and this shift also occurred in the area of athletics. Each city dealt with the expanded athletic activity in their own way. At Athens, it was evident that by the latter part of the fourth century B.C., the Agora was no longer capable of meeting the athletic demands of its citizens. Therefore, a large stadium was built to ease the burden of the combined commercial and civic activities and athletic functions of the Athenian Agora.

\section{Stadium (Stadion)}

Today, the word "Stadium" is very familiar to us, but it used to be a place for sport activities such as running, and national and ritual activities such as circus. Nowadays, we know little about ancient Stadiums. Probably, it is a rectangular area with circular ends, containing a small column near each end which runners would turn around them and get back to the starting point. There were no seats in the early Stadiums for those who watch the games but later some embank added to provide fans and judges with a place to sit during the game.

Running race was probably the most important sport in ancient Greece which was held at one Stad, which is about $182 \mathrm{~m}$ and the name "stadium" comes after Stad.

Only a small number of books have appeared on the Greek stadium. One by Romano examines the origins of this type, with particular focus on the Peloponnesos. He had previously studied stadia in the region for his dissertation. A book by Miller discusses the Hellenistic stadium uncovered by his excavation team at Nemea. Results of the affiliated excavations at Nemea which were revived by the University of California (UC) at Berkeley, show an early Hellenistic stadium.

In many Greek stadiums, the starting lines are made up of several blocks extending across the width of the running track. Typically, each individual block has two parallel grooves, stretching the width of each block with sockets for individual turning posts as at Olympia, Nemea, Delphi, and Epidaurus. This design would have required a close foot position at the start. At Corinth, however, the starting line nearly resembles a modern day starting line like those dug in the ground by sprinters before the introduction of starting blocks used in present day track events.

The earlier racecourse had a rise of ground south of the track that provided a good view for spectators and judges. The later track ran parallel with a building called the South Stoa which was built under the direction of Philip of Macedon's leadership. The South Stoa had many functions, however, the steps in front of the building were approximately three and one-half meters above the running track and provided an excellent area to watch the races.

\section{Stadium at Athenes}

During the peace time, Athenian men spent most of their time in Stadiums which usually were built outside the city and had too many facilities. Today only one of Athenian stadiums called Panathenaic or Kallimarmaro that was built about 329 B.C. still remains in existence. Panathenaic Stadium was expanded later in 140 A.D. and provided room for 50000 people. Later in 1896 , it was rebuilt to contain the beginning ceremony for the first modern Olympic.

Parthenon frieze is a record of different aspects of Athen's large stand most important athletic festival, the panathenaic games.

\section{Stadium at Aphrodisias}

A combination of stylistic and historical evidence suggests that the Stadium was part of the monumental building program undertaken in the city in the first century A.D. The Stadium has a peculiar form in that it has two sphendonai (curved ends) rather than one. It 
is one of a small group of such stadia in the Greek world that epigraphical evidence suggests had a specific name: oGTd8tov dt4pt0F'atpov ("amphitheatral stadium"). The unusually complete archaeological record at Aphrodisias indicates that throughout the Imperial period, the Stadium was used not only for Greek athletic competitions, but also for Roman spectacles such as gladiatorial games and venationes. In Late Antiquity, a small stone amphitheater was built into its eastern sphendone, obliterating part of the Stadium's running track.

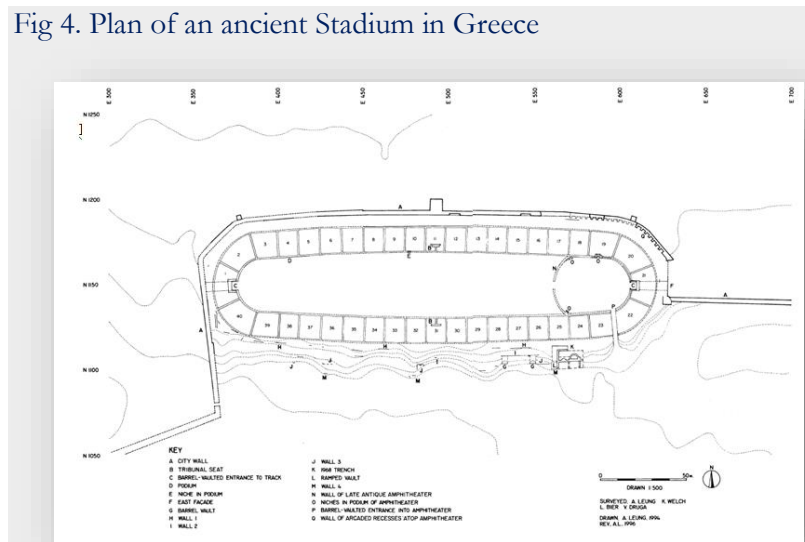

\section{The Stadium of Olympia}

The archaeological site of Olympia lies on a grassy plain in the present-day Greek province of Elia. The site was famous for the sanctuary devoted to Zeus and the Panhellenic games that took place every four years in honor of the god. The stadium we now see (Stadium III) was constructed towards the end of the fifth century B.C. The track was 600 Olympic feet long $(192.28 \mathrm{~m})$ and was of clay, levelled and thickly covered with sand; it had stone sills at each end which marked the start and finish of the races. The course was separated from the embankment by a ridge of stone blocks on the outside of which was a channel that ran round the stadium. The ground rises naturally to the east and artificial embankments were constructed on the north, west, and south sides. There was however as in all the fourth-century B.C. stadiums, no seating for the spectators. The stone elements of the stadium were very limited: a platform that supported seats for the Hellanodikai (judges), the balbis (the starting line of the races), and a drain running across the track to carry water away. After the Games officially ended in A.D 393, the site has suffered many natural disasters ever since, including earthquakes, fires, and floods.

\section{The Stadium of Nemea}

The site of Nemea lies in an upland valley in the modern province of Corinthia. On the floor of the valley nestles a small village called Ancient Nemea or Herakleion. In ancient times, the site was famous for the Sanctuary of Zeus in which the temple to the god was dominant.

Fig 5. Aerial view of the Nemea stadium

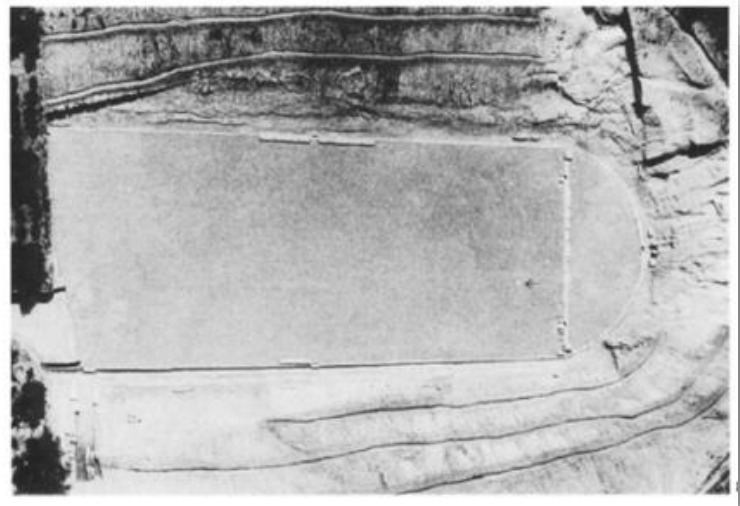


Fig 6. Nemea stadium at the 1977 excavation

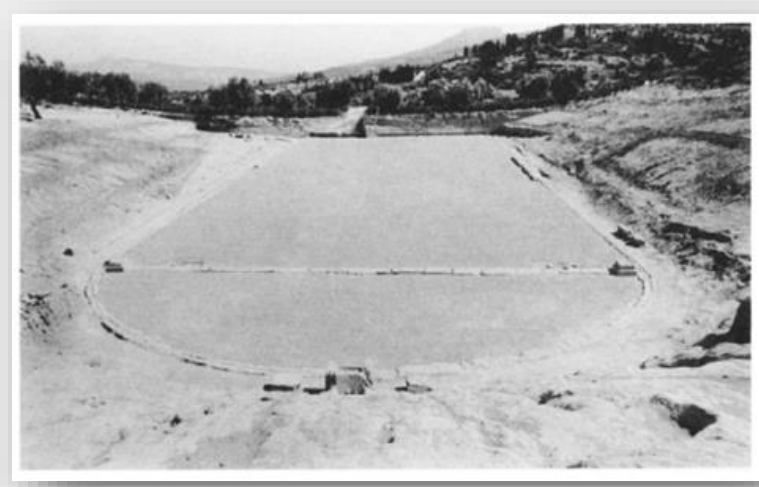

The Nemean Games took place every two years in two basic locales, the stadium and the hippodrome. According to evidence, around 415 B.C, the majority of the sanctuary of Zeus was destroyed and

consequently in the following years, the Games were held in Argos. In 330 B.C, the Argeians decided to undertake a building programmer in Nemea, including the reconstruction of the Temple of Zeus and the creation of the early Hellenistic Stadium. This stadium remained in use until 271 B.C, the year when the Games returned to Argos. The remains of the stadium lie $450 \mathrm{~m}$ south-west of the temple of Zeus. In a second natural depression east of the stadium lies the remains of a single rectangular building with a central portico, the Apodyterion (locker-room). In order to enter the stadium, the athletes had to cross the Hidden Entrance, the $36.35 \mathrm{~m}$ long tunnel which led to the western part of the track. The track of the stadium was 600 ancient feet of hard-packed yellow clay (MILLER, 2005: 205-07). At both ends of the track, a balbis or starting line was located. In addition to the stone starting line itself, the balbis included the hysplex, a starting mechanism allowing the athletes to have consistently fair starts to races.

The architectural form of gymnasion and its function are discussed very generally in a book on ancient athletics and are covered in more detail particularly for the Hellenistic period, in the proceedings of an international conference held in 2001. Individual gymnasia is found at Samos, Olympia, and Eretria. Such buildings may be located near or associated with others of related functions, including the palaestra at Olympia and a later (Roman) at Samos.

Since 1964, excavations at Eretria have been conducted by the Swiss School of Archaeology in Greece. Final reports are published in the Eretria series, which include a number of recent volumes on architecture. These cover topics range from houses to the gymnasion, the theater, and Macedonian-type tombs.

The most proper sample of a Gymnasion is the one which was built in Sardis during Hellenistic era.

The Gymnasium of the 'Lykeion', that scholars were trying to locate as early as late nineteenth century, was one of the three ancient Gymnasia of Athens which operated from the sixth century B.C.

\section{Palaestra}

Palaestra in fact was a wrestling school and arena, but sometimes mistaken with gymnasion. Some believe that the palaestra was a special building within ancient gymnasiums where wrestling and physical training were practiced (SALTUK, 1990).

Greek towns of substantial size also had a palaestra or a gymnasium, the social center for male citizens.

Due to the nature of wrestling game in ancient Greece, Palaestras were built near a river, usually outside of the city and were provided with facilities such as spectator areas, baths, toilets and club rooms.

Sand wrestling took place in the open court of the palaestra, and mud wrestling in some covered area where the mud would not dry as fast as in the hot Mediterranean sun. Mud 
wrestling also took place in the central court of the palaestra.

\section{Palaestra at Athens}

In 1996 on Rigillis street, in the center of Athens, rescue excavations conducted prior to the erection of the Museum of Modern Art uncovered archaeological remains of a large public building occupying an extended area of more than $3000 \mathrm{~m}^{2}$. It had been seriously damaged by the military installations which occupied the area from the nineteenth century until 1966. Besides the poor state of preservation, the ground plan of the building was restored. The site has been identified as a palaestra due to its size and the remarkably symmetrical arrangement of its rooms around a large rectangular court is surrounded by stoas. Its original plan was preserved throughout its period of usage from the late fourth century B.C until the end of the fourth century A.D, with repairs after every destruction.

\section{Palaestra at Olympia}

The Palaestra seen in the picture is built around a yard which is surrounded by columns that hide dressing rooms and bathrooms behind.

\section{REFERENCES}

AYTAÇ, K. Avrupa eğitim tarihi. Ankara: Dil ve Tarih-Coğrafya Fakültesi, 1980.

AZAD M, BARUA A, SULTANA SH. International journal of civil engineering, construction and estate management, Vol.3, no.2, pp 48-58, page 52, 2015.

BAHMANESH, A. Olympic Games, Book Publishing Esmaeili, MR., 2009, Physical Education and Sport, Tehran: Humanities Research and Development Organization of the Universities (position), Human Sciences Research and Development Center, 134.BALCI,
V. 2008. Anadolu'da antik spor alanları. Ankara: Ankara Üniversitesi, 1987.

BARLETTA A. B. Greek architecture, American journal of archaeology 115, pp 611640, page 618, 2011. https://doi.org/10.3764/aja.115.4. 0611

BARLETTA A. B. Greek architecture, American journal of archaeology 115, pp 611640, page 624,625, 2011. https://doi.org/10.3764/aja. 115.4.0611

MASTERSO, D. W. The ancient Greek origins of sports medicine, Br J Sports Med, pp 196-202, p. 198, 1976. https://doi.org/10.1136/bjsm. 10.4.196

DEMIREL D. YILDIRAN I. the philosophy of physical education and sport from ancient times to the enlightenmemnt. European Journal of Educational Research Vol. 2, No. 4, 191-202, page 191-193, 2016. https://doi. org/10.12973/eu-jer.2.4.191

DIMITRA-MARIA LALA. Contemporary Uses of Archaeological Sites: A Case Study of Ancient Stadiums in Modern Greece; conservation and mgmt of arch. sites, Vol. 16 No. 4, November 2014, 308-321, 2014. https://doi.org/ 10.1179/1350503315Z.000000000100

FARHADFAR, E. Physical Education and Sport, Third Edition, Tehran, Born 59,60 Ramezaninezhad, R. 2008. Physical Education and Sport Sciences, First Edition, North University, North Station Publishing House, 56, 2011.

THOMPSON, H.A. The Athenian Agora Guide (American School of Classical Studies at Athens) 1; and Noel Robertson, Festivals and Legends: The Formation of Greek Cities in the Light of Public Ritual (London, 1992):96, 1976.

HUGUENOT, C. La tombe aux Erotes et la tombe d'Amarynthos: Architecture funeraire et presence macedonienne en Grece centrale. 2 vols. Eretria 19. Gollion, Switzerland: Infolio. Respectively, 2008.

ISLER, H.P. Das Theater: Grabungen 1997 und 1998. Eretria 18. Lausanne and Gollion, Switzweland: Ecole Suisse d'Archeologie en Grece and Infolio, 2007. 
KAH, D., AND P. SCHOLZ, EDS. Das hellenistische Gymnasion. Wissenskultur und gesellschaftlicher Wandel 8. Berlin: AkademieVerlag, 2004. https://doi.org/10.1515/9783050084077

KYLE, D. Directions in ancient sport history. Journal of sport history, Vol.10, No.1, pp. 7 34, p 9, 1983.

LATTIPONGPUN, W. The origins of the Olympic games' opening and closing ceremonies: artistic creativity and communication, intercultural communication studies XIX:1, page 1031-2015. Ancient Olympic ks2, river and rowing museum, hanley-on-thames, 2010. LYGOURI-TOLIA, E. Excavating an Ancient Palaestra in Athens. In: M. Stamatopoulou and 56-M. Geroulanou, eds. Excavating Classical Culture: Recent Archaeological Discoveries in Greece. Oxford: Oxbow Books, pp. 203-12, 2002.

MANGO, E., P. GEX, P. ANDRE, AND M. JACCARD. Das Gymnasion. Eretria 13. Gollion, Switzerland: Ecole Suisse d'Archeologie en Grece, 2003.

MARTINI, W. Das Gymnasium von Samos. Samos 16. Bonn: Rudolf Habelt. miller 2001, 1984.

MILLER, S. Ancient Greek Athletics. Albertina: Yale University Press, p108, 2004a.

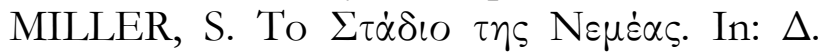

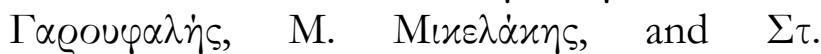

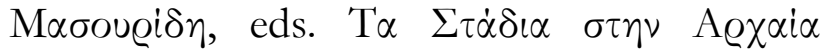

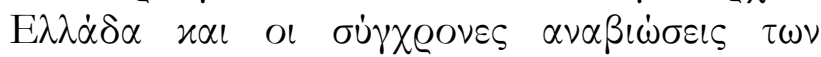
$\alpha \varrho \chi \alpha i \omega \nu ~ \alpha \gamma \dot{\omega} \nu \omega \nu$. Athens: Ekdoseis Periskopio, pp. 49-53.49, 2004b.

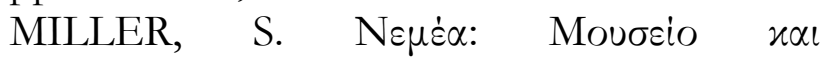
Aexaıdoywós Xígos. Athens: TAPA.17,2122, 2005.

MOUSTAKA, A. Grossplastik aus Ton in Olympia. OlForsch 22. Berlin: Walter de Gruyter, p. 31, 1993.

NEWBY, Z. Athletics in the Ancient World. London: Bristol Classical Press, 2006.

OST A., DEBORAH, A. BOUCHER, CHARLES. Fundamentals of Physical Education, Sport Sciences and Sports, Translation by Ahmad Azad, Tehran: Organization for the Study and Compilation of Human Sciences Books of Universities (position), Center for Human Sciences Research and Development; National Olympic Committee of the Islamic Republic of Iran, 215, 2011.

REBER, K. Die klassischen und hellenistischen Wohnhauser im Westquartier. Eretria 10. Lausanne: Editions Payot, 1998.

SABAGH LANGROUDI, M. Physical Education Date, Isfahan, Islamic Azad University, Khorasgan Branch, Research Deputy, 161, 2008.

SALTUK, S. Arkeoloji sözlüğü. İstanbul:İnk1lâp Kitabevi.SAVIC, Z. 2007. The Olympic games as a cultural event. Acta Univ. Palacki. Olomuc., Gymn., vol. 37, no. 3, pp 7 13, page 8,9, 1990.

SEE DUCREY, P., I.R. METZGER, AND K. REBER. Le quartier de la Masion aux mosaiques. Eretria 8. Lausanne: Editions Payot, 1993.

SWADDLING, J. The Ancient Olympic Games. London: British Museum Press, p 25, 1980.

VALAVANIS, P. Games and Sanctuaries in Ancient Greece: Olympia, Delphi, Isthmia, Nemea, Athens. Athens: Kapon, 156-159, 2004.

VUKOVIĆ, R. Forerunners, organizers, contestants and guests at the Olympic Games in Athens in 1896. Belgrade: "Logos" Totovo village. p 16, 2001.

WACKER, C. Das Gymnasion in Olympia: Geschichte und Funktion. Wurzburg: Ergon Verlag, 1996.

YAGHOUB A. History of Ancient Art, Position, Tehran, 354, 2011.

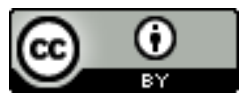

License information: This is an openaccess article distributed under the terms of the Creative Commons Attribution License, which permits unrestricted use, distribution, and reproduction in any medium, provided the original work is properly cited. 
Article received on August 30, 2019.

Evaluated October 21, 2019.

Accepted on November 01, 2019.

Published on November 21, 2019.

How cite this article (ABNT):

DEIMARY, Nima; AZIZI, Mahsa; MOHAMMADI, Mohammad. The study of the influence of ancient Greek rituals and sports and the formation of the architecture of its sports spaces. Estação Científica

(UNIFAP), Macapá, v. 9, n. 2, p. 33-44, apr./jun. 2019. 